\title{
The Slave Narrative in African-American Literature: A Study of Solomon Northup, Frederick Douglass and Harriet Jacobs
}

\author{
By Dr J.C. Chukwu (Reader) \\ Department of History \& International Relations, Abia State University, Uturu, Nigeria
}

DOI: $10.7176 / J L L L / 65-03$

Publication date: February $29^{\text {th }} 2020$

Between 1770 when Ukawsaw Gronniosaw's work announced the birth of the African-American literary tradition and 1860, the most dominant form of narrative focused on the experience of slavery as encountered by blacks in the United States. Although identifiable as a unique genre of its own, the typical slave narrative is essentially a form of autobiography. Generally speaking, an autobiography is a self portrait narrative construed and constructed by the subject himself.

Precisely, between 1820 and 1860, there were a wide range of publications by Afro-Americans on America's peculiar institution. These publications exposed in details their complex ethnical and psychological orientation toward slavery, demanding in very strict terms, the abolition of the Southern tyranny. It was these collective utterances that made up what the Afro-American writer, Arma Bontemps, calls an "'American genre" of literary narrative, otherwise known as "Slave narrative" (See Ogude $30-31$ ).

Written by ex-slaves, the narratives reveal a common pattern of representation, revealing the author's

circumstances and experiences under servitude, his heroic journey from slavery to freedom as well as his subsequent identification with the abolitionist cause, For instance, in the preface to her Narrative, Linda Brent aimed at arousing the members of the public, particularly, the women to rise up against the institution of slavery in the South in the spirit of abolitionist cause. Thus she says:

I have not written my experience in order to attract attention to myself; on the contrary, it would have been more pleasant to me to have been silent about my own history. Neither do I come to excite sympathy for my own sufferings. But I do earnestly desire to arouse the women of the North to a realizing sense of the condition of two millions of women at the South, still in bondage, suffering what I suffered, and most of them far worse. I want to add my testimony to that of able pens to convince the people of the free states what slavery really is. Only by experience can anyone realize how deep and dark and foul is that pit of abomination (6).

For our purpose, our focus in the present essay is to undertake a comparative study of three Afro-American slave narratives namely Twelve Years a Slave by Solomon Northup, An American Slave by Frederick Douglass and Incidents in the Life of a Slave Girl, by Harriet Jacobs. In doing these specific and crucial aspects of the narratives such as: region of servitude, life in the plantation, Master-slave relationship, religion and slavery, and education and slave emancipation will be highlighted and discussed. This is finally capped with a conclusion. An elaborate specification and description of the region of servitude involved is a fundamental aspect of the three slave narratives considered here. The three narratives focus on those Southern states of the United State of America characteristically branded slave states. In the slave states, agricultural economy prevailed. There were large-scale cotton, corn, sugar cane and tobacco plantations, where slaves were deployed to work under conditions of servitude.

Generally speaking, some states were referred to as slave states and they included; Texas, Louisiana, Florida, South Carolina, North Carolina, Georgia, Alabama, Missouri, Arkansas, Kentucky, Tennessee, Virginia and Delaware. On the other hand, non-scale states included: Utah, Oregon, New York, Vermont, New Hampshire, Michigan, Ohio, Pennsylvania, Miami, Massachusetts, Rhode Island, Connecticut, New Jersey, Indiana and Illinois.

Although Solomon was a free coloured citizen of New York City, he was kidnapped in 1841 in Washington City and for twelve years, he toiled and suffered as a slave until 1853 when he was rescued from a cotton plantation near the Red River in Louisiana state of the South. Under Servitude, he passed through a number of slave mates namely, William Ford, John Tibeats, Peter Tanner and Edwin Epps whom he served for ten years out of his twelve years as slave.

Linda Brent, the narrator of Incidents in the Life of a Slave Girl, also served in Louisiana, a state in the South. Her parents were slaves and so at birth, she automatically became a slave to the family where the parents were held in bondage. But her own brand of slavery or servitude would have been a happy experience because of the kindness of her premier mistress. The death of this kind mistress exposed Linda to a harrowing experience of her awful servitude in the hand of Dr. Flint and his family members to whom Linda was bequeathed.

Frederick Douglass too, was a Southern slave. He was born in 1818 as a slave boy to the family of Captain Aaron Anthony of Tuckahoe near Hillsborough, about twelve miles from Eastern Country in Maryland, His mother was Harriet Bailey's slave woman belonging to Captain Aaron Anthony a factor that automatically defined Douglass as a property of Captain Aaron Anthony. Like Solomon Northup, Douglass served a number of 
masters namely Captain Aaron Anthony, Mr. Hugh Auld, and Edward Covey from whom Douglass received the most unkindly and brutal treatment resulting in a hard resolution by Douglass who says, "I now resolved that, however long I might remain a slave in form, the day had passed forever when I could be a slave in fact"(8). He was devoted to this cause, so distinguishing himself as a free black seaman, he caught a train from Bath to Philadelphia in 1838, transferred to a New York bound train, and on the 3rd of September, gained his liberty.

In the southern states common slave laws operated. One of the basic slave laws was that which divested the slave of anything called right. He had no legal rights, no right to acquire education, had no right to resist sexual harassment by masters in the case of female slaves indeed he had no legal, social, political or any whatever.

An aspect of the law, which made a slave only a chattel or property belonging to the owner, therefore covered this state of a slave. A slave became a property of the master on various conditions. One was by purchase, Many slaves from African were sold in America. Phillis Wheatley, for instance, was an African brought to America in 1761 and sold at Boston slave market to John Wheatley.

The slave laws too prohibited a free movement of slaves or any coloured person in the South. Thus, any coloured person, be he a free citizen or slave, he must move out only with a pass from the master or a free paper indicating his state, otherwise, he was bound to be kidnapped, sent back to the master resold or imprisoned as a runaway slave. This was aimed at checking the instance of runaway slaves.

The law, however, forbade the kidnapping of Solomon Northup an illegal and unfortunate incident. Referring to James Burch the slave trader who bought him from Brown and Hamilton and who ordered Solomon never to mention to anyone the fact of his free citizen of New York, recognizing the legal implication of the deed, Solomon remarks: I doubt not he understood then better than I did, the danger and penalty of selling a free man into slavery, He felt the necessity of closing my mouth against the crime he knew he was committing (8).

Another means of owning slaves was by inheriting the offspring of one's slaves, Frederick Douglass became a slave to his master or father by virtue of the fact that his mother was a property of the master. In the same manner, Linda Brent was a slave to the former mistress owing to the fact that her parents were slaves to the same mistress.

Ownership of a slave could come by way of the will of a former or deceased master. Legally, the will of a slave holder would usually determine or direct the fate of his or her slaves. Some could direct the freeing of the slave as in the case of the father of Solomon Northup; he could equally direct that the slaves be bequeathed to a person of his will as in the case of Linda Brent who said thus: "After a brief period of suspense, the will of my mistress was read, and we learned that she had bequeathed me to her sister's daughter a child of five years old. So vanished our hope.,."(16), Whether a slave was procured from a slave market, or through the direction of the will of the former master, or through birth of the master's slaves, they were all rated equally before the law. According to Frederick Douglass: "We were all ranked together at the valuation. Men and women, old and young, married and unmarried, were ranked with horse, sheep and swine"(18). The satanic attitude meted out to the black slaves could qualify as the gravest inhumanity to man on earth.

Another aspect of the slave law was that which bestowed overwhelming powers on the slave holders against their slaves. Slavery in the Southern States presented a picture of a situation where the slave had no right of his own, while on the other hand, his master had every right to exercise whatever powers on him, including the right to kill, serve, whip, sell, and even rape the slave girl or woman without answering for it before the law,

Moreover, working in the plantations in America proved another harrowing experience. Solomon Northup and Frederick Douglass were plantation slaves and much of their narrative is devoted to life of slaves in plantation service. Harriet Jacobs only gives a little attention to life in plantation. The extent of coverage of each narrative would appear to depict the period and experience of each narrator in plantation service. For Solomon, virtually the whole period of his 12 years of servitude was spent in the plantation. Under Edwin Epps with whom he spent ten years, he was engaged in cotton and sugar plantations, which were the dominant occupations in the plantations around Bayon Boenf.

Similarly, Frederick Douglass was a plantation slave. But unlike Solomon Northup who came into the plantation service at an adult age of thirty-two, Douglass was born and bred in the plantation environment. However, he does not go into the plantation services as a slave until he came to the age of six and seven. So, he was most of the time in the service of the grandmother, as the mother, a slave was rarely seen by him. Douglass confirms this thus: "I never saw my mother to know her as such, more than four or five times in my life; and each of those times was very short in duration..." (48).

It was probably as a result of this confinement with the grandmother that he became insulated from the horrors of the plantation life until he grew up to get exposed and astonished to it. Referring to the whipping of a slave in the plantation probably for the first time, he says:

I was so terrified and horror -stricken at the sight, that I hid myself in a closet, and dared not venture out till long after the bloody transaction was over. I expected it would be my turn next. It was all new to me, I had never seen anything like it before. I had always lived with my grandmother on the outskirts of the plantation, where she was put to raise the children of the younger women. I had therefore been, until now, out of the way of the bloody 
scenes that often occurred on the plantation (52). It was a startling experience to him.

Generally, there were various kinds of plantations with various sizes, in the Southern states. The commonest ones included cotton, wheat, corn, sugar and tobacco. Frederick Douglass passed through a number of masters namely Captain Aaron Anthony, Mr. Hugh Auld and Edward Covey. Describing the size of Colonel Lloyd's plantation, where the master Captain Aaron Anthony served as overseer, Douglass says:

The plantation is about 12 miles north of Eastern, in Talbot country, and is situated on the border to Miles River, The principal products raised upon it were tobacco, corn and wheat. These were raised in great abundance, so that, with the products of this and the other farms belonging to him, he was able to keep in almost constant employment a large sloop in carrying them to market in Baltirno (5)

In her own narrative, Linda Brent reveals the existence of domestic or town slaves in the Southern states, of which she was one. According to her, she had only a very short period in the plantation. As a matter of fact, her deployment to the plantation was for her to submit to the sexual demands by her master, Dr. Flint. In one of his threats to Linda, Dr. Flint remarks:3).

You must either accept my offer, or you and your children shall be sent to your young master's plantation, there to remain till your young mistress is married; and your children shall fare like the rest of the Negro children. I give you a week to consider of it (128).

It was the persistent failure of Linda to yield that made Dr. Flint to pronounce her redeployment to the plantation, saying:

... Very well, go to the plantation and my curse go with you... your boy shall be put to work, and he shall soon be sold, and your girl shall be raised for the purpose of selling. We//, go Yourway(128).

Ordinarily, plantation service was more tasking. More horrifying than domestic or town service. The news about the redeployment of Linda to the plantation exacted the fears of Linda's grandmother who did not hesitate to accost both Linda and Dr. Flint, the master, To Linda, she asks, "Linda, you go?.,, can't something be done to stop it?( 132). The ostensible reason given to Linda's grandmother of Dr. Flint was that what he did was in the interest of Linda, because she was having feelings entirely about her situation, and that, on the plantation she would receive treatment suitable to her behaviour.

Douglass gives a comparative consideration of the town and plantation slaves in terms of tasks performed and treatment meted out to them respectively. In his summation: A city slave is almost a freeman compared with a slave in the plantation. He is much better fed and clothed, and enjoys privileges altogether unknown to the slave on the plantation, There is a vesting of decency, a sense of shame that does much to curb and check those outbreaks of atrocious cruelty so commonly enacted upon the plantation (79-80).

In other words, the thrust of the agony of slavery is best demonstrated with the plantation -service of Linda, Solomon and Douglass. Linda reveals the target of sending her to the plantation and the intention of the young master to make good this target. For instance, Mr. Flint, her young master referring to Linda, records:

"I've got her down here, and I' II soon take the town notions out of her head. My father is partly to blame for her nonsense. He ought to have broken her in long ago..." (132).

As pointed out above, unlike Linda, the thrust of Northup and Douglass narratives is on plantation service. Narrating his bitter experience in the plantation under Edwin Epps, Solomon Northup recounts:

The hands are required to be in the cotton fields as soon as it is light in the morning and with the exception of ten or fifteen minutes which is given them at noon to swallow their allowance of cold bacon, they are not permitted to be a moment idle until it is too dark to see, and when the moon is full, they do not dare to stop even at dinner time, nor return to the quarters, however late it be until the order to halt is given by the drive. No matter how fatigued and weary he may be no matter how long he longs for sleep and rest a slave never approaches the gin house with his basket of cotton, but with fear. If it falls short in weight if he has exceeded it by 10 or 20 pounds, in all probability his master will measure the next day's task accordingly... After weighing, the whippings (126).

Another issue considered by the three narratives, which is of great importance, centres on the plantation officials. Particularly Solomon Northup and Douglass devote attention to the discussion on these officials, which include plantation owners, overseers, drivers and even patrollers. Plantation owners with large estate employing between fifty and two hundred hands (slaves), the services of an overseer was indispensable. Describing the role and outfit of an overseer, Northup says: 
Overseers ride into the field on horseback, without exception, to my knowledge, armed with pistols, bowie knife, whip, and accompanied by several dogs. The fellow thus equipped, stood in rear of the slaves, keep a sharp look out upon them all. The heartlessness, brutality and cruelty. It is his business to produce large crops, and if that is accomplished, no matter what amount of suffering It may have cost. The presence of the dogs is necessary to overhaul a fugitive who may take to his heels as is sometimes the case when faint or sick, is the whip. The pistols are reserved for any dangerous emergency...even when the slave will sometimes turn upon his oppressor,.,(171).

Describing the attitude of Mr. Gove, the overseer under Colonel Lloyd, Douglass discloses: It is better that a dozen slaves suffer under the lash than that the overseer should be convicted, in the presence of the slaves of having been at fault. No matter how Innocent a slave might be it availed him nothing, when accused by Mr. Gove of any misdemeanor. To be accused, was to be convicted, was to be punished, the one always following the other with immutable certainty ...when he whipped, he seemed to do so from a sense of duty, and feared no consequences... his consummate coolness with which he committed the grossest and most savage deeds upon the slaves under his charge (65-66).

There is no doubt that overseers were men of harsh and strict character, but even Douglass observes that "overseers will sometimes indulge in a witty word, even with the slaves." So, individual difference in character among men must exert some influences among overseers despite the strict demands of their tasks on cruelty and high-handedness. So, Mr. Grove could just be an extreme type of cruel overseers. Solomon Nothup, in his narrative, indicates how he narrowly escaped death in the hands of his wicked master, John Tibeats, as a result of the quick intervention of Mr. Chapin, the overseer. According to the narrative, as John Tibeats and his agents were dragging him towards the tree, Mr. Chapin moved straight to them and spoke in a firm, determined manner as follows:

Gentleman, I have a few words to say, you had better listen to them. Whoever moves that slave another foot from where he stands is a dead man. In the first place, he does not deserve this treatment. It is a shame to murder him in this manner I never knew a more faithful boy than Platt (Solomon). You, Tibeats, are in the fault yourself... I have been in the plantation for seven year... (83)

Under the overseer, were drives that were mainly blacks. In addition to the performance of their equal share of work, they were compelled to do the whipping of their several gangs. Whips hung around their necks and if they failed to use them thoroughly they were whipped themselves. Solomon was a driver in Edwin Epps ${ }^{1}$ plantation and he has this to say-about his experience as a driver:

During my eight years experience as a driver, I learned to handle my whip with marvelous dexterity and precision, throwing the lash within a hair's breadth of the back, the ear, the nose, without, however, touching either of them. If Epps was observed at a distance, or we had reason to apprehend he was sneaking somewhere in the vicinity, I would commence plying the lash vigorously, when, according to arrangement, they would squirm and screech as if in agony, although not one of them had in fact been even grazed (172).

Other aspects of plantation life covered by the narratives were the mode of supplies to the slaves; provision of allowances to the slaves as well as the resting days for slaves. Describing the culture of handling slaves in Colonel Edward Lloyd's plantation, Solomon informs us:

...it was here too, the slaves of all the other farms received their monthly allowances of food, and their yearly clothing. The men and women slaves received as their monthly allowance of food, eight pounds of pork, or its equivalent in fish, and one bushel of com - meal. Their yearly clothing consisted of two coarse linen shirts, one pair of linen trousers, like the shirts one jacket, one pair of stockings, and one pair of shoes, the whole of which could not have cost more than seven dollars. The allowance of the slave children was given to their mother, or the old women having the care of them... when these failed, then they went naked until the next allowance day., ,(59-60),

Such an arrangement was completely absent in Louisiana State. Solomon Northup narrating how he and other slaves fended for themselves, using their earning on Sabbath days to cater for their needs of food and clothings, we are informed at length:

It is the custom in Louisiana, as I presume it is in other states to allow the slave to retain whatever compensation he may obtain for services performed on Sundays. In this way, only, are they able to provide themselves with any luxury or convenience whatsoever. When a slave, purchased, or kidnapped in 
the North, is transported to a cabin on Bayon Beonf, he is furnished with neither knife, nor fork, nor dish nor kettle, nor any other thing in the shape of crockery, or furniture of any nature or description. He is furnished with a blanket before he reaches there, and wrapping that around him, he can either stand up or lie down upon the ground, or on a board, if his master has no use for it. He is at liberty to find a gourd in which to keep his meal, or he can eat his own from the cob, just as he pleases. To ask the master for a knife or skillet, or any small convenience of the kind, will be answered with a kick, or laughed at, as a joke. Whatever necessary article of this nature found in the cabin has been purchased with Sunday money (1 48).

In her own narrative, Linda does not demonstrate any clear arrangement regarding the maintenance and sustenance of the slaves in the plantation. She says: "My task was to fit up the house for the reception of the bride. In the midst of shoots, table cloths, towels, drapery, and carpeting, any head was as busy planning, as were my fingers with the needles"(131).

So, Linda was actually not involved in fieldwork. However, there was every indication that slaves were in the same state of want as slaves in other parts of the South. This was true, considering various arrangements by Linda to obtain supplies of food from her grandmother. Thus, she says;

I wished to appear as contented as possible. Sometimes, I had an opportunity to send a few lines home; and this brought up recollections that made it difficult, for a time, to seem calm and indifferent to my lot. , . I have been three weeks on the plantation, when I planned a visit home. It must be at night, after everybody was in bed. I was six miles from town, and the road was very dreary, $i$ was to go with a young man, who, I knew, often stole to town to see his mother.. .(132-3).

The narratives also consider the issue of holidays for slaves in plantation. There were certain differences discernible in the conditions of the holidays. Douglass, narrating his experience under the service of Mr. Edward Covey concerning the Christmas holidays of 1883, makes us to know:

The days between Christmas and New Year's Day are allowed as holidays; and so accordingly we were not required to perform any labour, more than to feed and take care of the stock. This time we pleased, this time, however, was spent in various ways. They stayed sober, thinking and industrious ones of our number would employ themselves in making com brooms, mats, horse collars, and baskets and another class of us would spend the part engaged in such sports and merriments as playing ball, wrestling, running foot races,.,(144).

Similar arrangement for Christmas also took place in Bayon Boenf, Louisiana state among the slaves of Mr. Edwin Epps, Narrating on this, Solomon points out:

It was Christmas morning the happiest day in the whole year for the slave, that morning he need not hurry to the field, with his gourd and cotton bay. Happiness sparkled in the eyes and overspread the countenances of all. The time of feasting and dancing had come. The cane and cotton fields were deserted. That day, the clean dress was to be downed the red ribbon displayed; there were to be re-unions, and joy and laughter....it was to be a day of liberty among the children of slavery... (218).

However, the duration of the Christmas holiday was limited to only three days, with effect from the Christmas clay. Linda also gives a vivid account of Christmas in her narrative. According to her:

Christmas is a day of feasting, both with white and coloured people. Slaves, who are lucky enough to have a few shillings, are sure to spend them for good eating; and many a turkey and pig is captured, without saying, "By your leave, sir," Those savory dishes can be made (181).

But here, Linda points out that the festival mood of the Christmas was punctuated by the uncertainty of the hiring day, which was the first of every January, when slaves were hired out to new masters, and so Linda remarks: "Were it not that hiring day is near at hand and many families are fearfully looking forward to the probability of separation in a few days, Christmas might be a happy season for the poor slaves..." (179).

Generally, some kind and philanthropic slave masters organized Christmas parties for the slaves. It was open to any slave from anywhere. Slaves too, were at liberty to organize the Christmas parties themselves if they had the resources to do so. Solomon narrates his story about the Christmas party organized for slaves by Miss Mary McCoy and we hear:

She is the beauty and the glory of Bayon Boenf.,, she owns about a hundred working hands, besides, a great many house servants, yard boys, and young children. She is beloved by all her slaves, and good reason indeed has they to be thankful that they have fallen into such gentle hands. Nowhere on the Bayon are there such gentle feasts, such Merry-making, as at young madam 
McCoy's, Thither more than any other place do the old and the young for miles around love to repair... holidays: for nowhere else can they find a delicious repasts; nowhere else can they hear a voice speaking to them so pleasantly. None is so well beloved no one fills so large a space in the hearts of a thousand slaves as young madam McCoy the orphan mistress of the Old Norwood estate (220).

Commenting on the Christmas holidays and their impact on slaves, Douglass states:

From what I know of the effect of these holidays upon the slave, I believe them to be among the most effective means in the hands of the slave holder in keeping down the spirit of insurrection. Were the slave holders at once to abandon this practice, I have not the slightest doubt it would lead to an immediate insurrection among the slaves. These holidays serve as conductors or safety-valves, to carry off the rebellious spirit of enslaved humanity. ...(115).

Solomon recounts the kind and humane character of one of his masters, Mr. William Ford whom he categorizes with his wife as practicing Christmas. Referring to Ford, Solomon Nortnup recounts: Perhaps, no other factor can determine the overall fate by $a$ slave more than the attitude of the master towards him. There were laws guiding the operations of the institution of slavery and most of these favoured the master. Yet there were few that guard against certain inhuman and cruel attitudes of the slave holders against heir slaves. We have cited above the intervention of Mr. Chapin to rescue Solomon Northup (Platt) from the wicked slave master, John Tibeats, His intervention was effective when he drew the attention of Mr Tibeats and his agents to the law of the land regarding the treatment of slaves, which they were violating. Thus, Mr. Chapin warns,"... you have no right to take it (Platt) anyway. There is a law for the slave as well as for the whiteman. You are no better than a murderer"(83).

But whatever the law says, the fate of the slave was largely determined by God and the slave holder, the slave was ultimately legally disadvantaged. Hence, he could not even challenge the illegality of his master's actions against him as he was a mere property of the master, having no right of his own. Despite the handicap of slaves, there were masters who established cordial relationship with their slaves while a large number of slaves are the objects of hate, cruelty, whip and all sorts of inhuman attitudes anyone can mention. The three narratives we are concerned with, deal extensively on this subject. In his narrative,

During my residence with Master Ford, I had seen only the bright side of slavery. His was no heavy hand crushing us to the earth. He pointed upwards and with benign and choiring words addressed us as his fellow mortals, accountable like himself to the maker of us all. I think of him with affection and had my family been with me, I could have borne his gentle servitude, without murmuring all my days: (74),

Frederick Douglass equally had a kind and benign master in the person of Mr. Freeland. Referring to this kind master, Douglass reminisces:

Though not rich, he was what would be called an educated southern gentlemen,. ,Mr. Freeland had many of the faults peculiar to slave holders, such as being passionate and fretful: but I must do him the justice to say, that he was exceedingly free from those degrading vices to which $\mathrm{Mr}$. Covey was constantly addicted., .was open and frank, and we always knew where to find him. He, like Mr, Covey, gave us enough to eat; but unlike Mr, Covey, also gave us sufficient time to take our meals. He worked us hard, but always between sunrise and sunset. He required good deal of work to be done, but gave us good tools with which to work...my treatment while in his employment, was heavenly, compared with what I experienced at the hands of Mr. Edward Covey (35).

Linda Brent equally presents a very interesting picture of positive master slave relationship. In the narrative, she reveals the extreme kindness of her mistress who permitted her (Linda's) father, a slave of the same mistress, to hire out his labour, so as to obtain money, for the purpose of redeeming both himself, and members of his family. Narrating this, she recounts as follow:

My father was a carpenter, and considered so intelligent and skilful in his trade, that when building out of the common line were to be head workman. On condition of paying his mistress two hundred dollars a year, and supporting himself, he was allowed to work at his trade, and manage his own affairs. His strongest wish was to purchase his children; but though he several times offered his hard earning for that purpose, he never succeeded (11).

This situation is most striking and better appreciated ' when one considers the fact that if there was anything a slave holder would detest as no matter how dearly or strained the relationship would be. 
In another occasion, the kindness of the same mistress was extolled even after her death. Pouring out the lamentation of her heart at the death of her mistress, Linda Brent records: I felt sure I should never find another mistress so kind as the one who was gone. She had promised my dying mother that her children should never suffer for anything; and when I remembered that, and recalled her many proofs of attachment to me, I could not help having some hopes that she had left me free.., as a child, I loved my mistress; and, looking back on the happy days I spent with her while I was with her, she taught me to read and spell; and for this privilege which so rarely falls to the lot of a slave, I bless her memory (15-16).

The institution of slavery had a secret which only kind slave holders understood and benefited from. This was the secret showing love and kindness to slaves. Every evidence points to the fact that kind slave holders benefited immensely from the service of their slaves who felt freely and worked freely to the satisfaction of their masters. Commenting on their service to their kind master, Mr. William Ford Solomon is of a frank talk:

It is a fact I have more than once observed that those who treated their slave most leniently were rewarded by the greatest amount of labour. I know it from my own experience. It was a source of pleasure to surprise master Ford with greater day, work than was required, while under subsequent masters, there was no prompter to extra effort but the overseer's lash (69).

While there were just few kind slave masters, the cruel and wicked slave holders were legion. The three narratives-of study provide classical examples of wicked slave holders as well as the true test of their cruelty against their slaves under plantation or town environment. The agony of a slave girl under a wicked slave master is also examined. The case of a slave girl, Linda Brant, and the master, Dr. Flint, is a pathetic one, which border's on sexual harassment, which leads Dr. Flint to invoke all sorts of inhumanity to torture Linda and wax her into submission. In fairness to Dr. Flint, he originally applied some subtle means in his seduction attempts; he showed her love, made promises to her including the promise of freedom to Linda and her children, only if she would yield to his sexual demands. Even in occasions when Dr. Flint had to exact forceful measures, he had later pleaded with Linda for forgiveness, and always pointing to his request and wishing that, Linda would relent and grant, Linda recounts her ordeals: But, I now entered on my fifteenth year a sad epoch in the life of a slave girl. My master began to whisper foul words in my ear. Young as I was, I would not remain ignorant of their import. I tried to treat them with indifference or contempt... he told me I was his property; that I must subject to his mean in all things. My soul revolted against the mean tyranny. But where would I turn for protection, when I succeeded in turn avoiding opportunities for him to talk to me at home, I was ordered to come to his office to do some errand. When there, I was obliged to stand and listen to such language as he saw fit to address me. Sometimes, I so openly expressed my contempt for him that he would become violently enraged...he threatened me with death and worse than death, if I made my complaint to my grandmother (49-50).

Wicked slave holders could go to any length to exhibit their wickedness against their slaves. Even the promises Dr. Flint made to Linda would appear unfulfillable and therefore wicked; they were merely aimed at seducing the poor slave. Thus, Linda reminds us:

I knew that my master's offer was a snare, and that if I entered, its escape would be impossible. As for his promise, I knew him so well that I was sure if he gave me free papers, they would be so managed as to have no legal value. The - alternative was inevitable (128).

Even Mrs. Flint was unkind to Linda as she suspected a shady deal between her (Linda) and her husband, Dr. Flint. On this, Linda says:

My mistress grew weary of her vigils; they did not prove satisfactory. She changed her tactics. She now tried the trick of accusing my master of crime in my presence, and gave my name as the authorofthe accusation...(54).

The nature of relationship between masters and their slave girls varied. Linda's case with her master was just a typical example of a case where a slave holder failed to make a sexual break into her slave girl. This is however, a very rare example. There were cases where slave girls freely submitted, or were forced to submit. Frederick Douglass in his narrative to draw attention to the fate of slave children of white parentage, using him as an example. He recounts thus:

I never saw my mother to know her so much, more than four or five times in my life; and each of those was not allowed to be present during her illness, at her death, or burial., .called thus suddenly away, she left me without the slightest intimation of who my father was. The whisper that my master was my father, may or may not be true; and true or false, it is of but little consequence to my purpose whilst the fact remains in all its glaring 
odiousness, that slave holders have ordained, and bylaw established that the children of slave women shall in all case follow the condition of their mothers; and this is done too obviously to administer to their own lusts,,, by this cunning arrangement, the slave holder, in cases not a few, sustains to his slaves the double relation of master hardships, and have more to contend with, than others. They are in the first place, a constant offence to their mistress. She is ever disposed to find fault with them; they can seldom do anything to please her...the master is frequently compelled to sell this class of his slaves, out of deference to the feelings of his white wife... (48-9).

Yet there was a case where a couple, Mr. \& Mrs. Covey arranged a meeting of a woman slave and a man for the purpose of raising slave children for them for economic reasons. Narrating such an incident, Douglass says:

Mr. Covey was a poor man; he was just commencing in life; he was only able to buy one slave; and shocking, as is the fact, he bought her as he said for a feeder. This woman was named Caroline Mr. Covey bought her from Mr. Thomas Lowe...After buying her, he hired a married man of Mr. Samuel Harrison, to live with him one year and he used to fasten up with her every night The result was that at the and of the year, the miserable woman gave birth to twins. At this result, Mr. Covey seemed to be highly pleased; both with the man and the wretched woman ...the children were regarded as being quite an addition to his wealth (105).

As shown above, harassment of female slaves by their masters was a common scene in Southern states. But there were few exceptions to the rule as demonstrated in the case of Phillis Wheatley who was girl under Mr. and Mrs. John Wheatley. They showed true love and kindness to her part and parcel of their family despite her status as a slave. There was no sign of sexual harassment, nor was there any intention by the master to use her for the purpose of raising offerings for the economic or social needs of the family. The sole aim of purchasing Phillis at the Boston slave market was to cater for the couple at their old age (40-41). Phillis at the appointed time got married to the man of her choice without any infringement on her rights or wishes by the master or mistress Mr. and Mrs. John Wheatley. As already pointed out, the case of Phillis Wheatley was indeed an exception to the rule. There was the general notion as expressed by Linda that:

...The value of female slaves derived not only from their worth, but also from their ability to bear and rear children, the human property upon which the slave system depended... the slave codes drew no distinction between the slaves' sexual autonomy and the masters' property lights: slave women were thus subjected to rape and to force liaisons that both satisfied their masters' sexual desires and increased their capital accumulation (xxxi).

So far we have been talking about special cruelty against female slaves based on sexual harassment. Virtually, every slave narrative devotes attention to highlighting the nature of cruelty and inhumanity meted out to slaves generally, by their slave masters. In his narrative, for instance, Frederick Douglass gives a clear picture of the fate of slaves under a wicked master, Mr. Rugby Hopkin:

Mr. Rugby Hopkin could always find some excuse for whipping a slave. It would astonish one unaccustomed to a slave holder life, to see with what wonderful ease a slave holder can find things of which to make occasion to whip a slave. A mere look, word or motion, a mistake, accident or want of power are all matters for which a slave may be whipped out, Does he speak loudly when spoken to by his master? Then he is getting high minded, and should be taken down, a buttonhole lower. Does he forget to put off his hat at the approach of a Whiteman? Then he is wanting in reverence, and should be whipped for it. Does he ever venture to vindicate his conduct, when censured for it? Then he is guilty of impudence one of the greatest crimes of which a slave can be guilty Does he ever venture to suggest a different mode of things from that pointed out by this master? $\mathrm{He}$ is indeed presumptuous and getting above himself, and nothing less than flogging will do for it (119-120).

Similarly, Northup in his narrative gives a description of master-slave relationship under a wicked slave holder, with particular reference to slaves under Edwin Epps whom he served for ten out of his twelve years, a slave. He recounts: Epps was wicked and exploitative. Ten years I toiled for that man without reward. Ten years of my incessant labour has contributed to increase the bulk of his possessions. Ten years I was compelled to address him with down-cast eyes and uncovered head in the attitude and language of a slave. I am indebted to him for nothing, save undeserved abuse and stripes... To speak truthfully of Edwin Epps would be to say he is a man in whose heart the quality of kindness or of justice is not found. A rough rude energy, united with an uncultivated characteristics. He is known as a "nigger breaker" distinguished for his faculty of subduing the spirit of the slave, and providing himself upon his reputation in this respect...he looked upon a coloured man, not as a human being, responsible to his creator for the small talent entrusted to him, but as a "Chattel person" as mere live property no better except in value, than his mule or dog (137).

Apart from Dr. Flint's sexual harassment against which had been discussed above, Linda highlights the 
negative attitudes of Dr. Flint to his slaves generally. In one occasion, she focuses on the method of feeding the slaves:

Little attention was paid to the slaves' meals in Dr. Flint's house. If they could catch a bit of food while it was going on, well and good I gave myself no trouble on that score, for on my various errands, I passed my grandmother's house where there was always something to spare for me. I was frequently threatened with punishment if I stepped there; and my grandmother to avoid detaining me often stood at the gate with something for my breakfast or dinner (19).

Douglass had viewed the cruelty of providing insufficient food for slaves very seriously in his reaction to the attitude of one Master Thomas, to his slaves. Douglass reminds us:

I have said Master Thomas was a mean man. He was so. NOT TO GIVE A

SLAVE ENOUGH TO EAT is regarded as the most aggravated development of meanness even among slave holders. The rule is, no matter how coarse the food, only let there be enough. This is the theory and in the part of Maryland from which I came, it is the general practice though there are many exceptions Master Thomas gave us enough of neither coarse nor fine food. We were therefore reduced to the wretched necessity of living at the expense of our neighbours through begging and stealing, whichever came handy in the time of need (96).

Generally speaking, slavery stood for cruelty, wickedness and exploitation. The existence of a kind slave holder would be an oddity in the system and on this one could rather accept the view of Linda Brent thus:

I could tell of more slave holders as cruel as those I have described. There are no exceptions to the rule, I do not say there are no humane slave holders. Such characters do exist, notwithstanding the hardening influences' around them, But they are like angels' visit few and far between (94).

Severally, slave holders particularly the wicked ones, sought for ways and means of justifying their nefarious and dastardly acts, using the biblical injunctions. There was a case of one Mr. Tanner, a slave holder under whom Solomon Northup served briefly who erroneously cited sections of the bible to justify his inhumanity to the slave. According to Northup's narrative/testimony:

Like William Ford, his brother NrHew, Tanner was in the habit of reading the bible to his slaves on the Sabbath, but in a somewhat different spirit. He was an impressive commentator on the New Testament. The first Sunday after my coming to the plantation, he called us together, and began to read the twelfth chapter of Luke. When he came to the 47th verse, he looked deliberately around him and continued "and that servant which knew his Lord's will... prepared not himself neither did according to his will, shall be beaten with many stripes:, " $\mathrm{D}^{1}$ ye hear that... "that nigger that don't take care that don't obey his Lord that's his master d 'ye ses? that 'ere nigger shall be beaten with many stripes. Now, "many" signifies a great many forty, a hundred, a hundred and fifty lashes. That's scripter"(104).

Here, Mr. Tanner equates the Lord of the scriptures with the lord of the slaves or slave master. Therefore, non-performance of a slave according to the exact will of his master attracted a punishment justifiable by the scriptures. Linda Brent also indicates a ploy of using the scriptures by a Reverend gentleman, Mr. Pike, to make slaves submit to their masters. Taking a portion of the scriptures which reads as follows: "Servant be obedient to them that are your masters according to the flesh, with fear and trembling in singleness of your heart, as unto' Christ" (53). The Reverend gave the following sermons aimed at inculcating discipline in the slaves. He reads:

...You men steal away to every grog shop to sell your master's corn that you may buy rum to drink. God sees you. You snack info the back streets, or among the bushes, to pitch coppers. Although your master may not find you out, God sees you; and he will punish you. You must forsake your sinful ways, and be faithful servants. Obey your old master and your young master, your old mistress and your young mistress. If you disobey your earthly master, you offend your heavenly master, when you go from here, don't stop at the corners of the street to talk, but go directly home, and let your master and mistress see that you have come (104).

The above 'sermon', like the former, justified the institution of slavery and therefore went on to inculcate in the slaves the sense of discipline and submissiveness to their masters, in order to sustain the system. No wonder, Karl Marx opines religion being the opium of the people. Here, religion was applied to crush and subjugate the slave spiritually so as to create more bases for further dehumanizing of the slaves physically.

There was also a horrorful story in Frederick Douglass" narrative about religionist slave masters generally. He appeared to have a blanket ruling about religionist slave dealers; but thank God, he somewhere showed a little distinction between the extreme wickedness of people like Rev. Daniel Weeded, Rev. Rugby Hopkin, and Mr. Freeland He says: 
I assert most unhesitatingly that the religion of the South is a mere covering for the most horrid crimes a justifier of the most appealing barbarity, a sanctifier of the most hateful frauds, and a dark shelter, under which the darkest, foulest, grossest, and most internal deeds of slave holders find the strongest protection. Were I to be again reduced to the chains of slavery, next to that enslavement, I should regard being the slave of a religious master, the greatest calamity that could befall me. For, of all slave holders with the worst. I have ever met, religious slaveholders are the worst I have ever found them the meanest and basest, the most cruel and cowardly, of all others. It was my unhappy lot not only to belong to religious slaveholders, but to live in a community of such religionists. Very near Mr. Freeland lived the Rev. Daniel Weeden, and in the same neighbourhood lived the Rev. Rugby Hopkins, These were members and ministers in the Reformed Methodist Church. Mr. Weeden owned among others, a woman slave... this woman's back for weeks, was kept laterally raw, made so by the lash of this witless, religious wretch. He used to hire hands. His maxims was, behaving well or behave ill, it is the duty of a master occasionally to whip a slave, to remind him of his master's authority. Such was his theory and such his practice (117-8).

Freedom is an inalienable right of man from birth. This and indeed other basic rights of man were completely denied the slave. Despite the ugly and social stigma of slavery as an institution, there were protagonists and campaigners who favoured and extolled the operation of the slavery institution in Southern states, A story was told of one Reverend gentleman who visited the South on an invitation by a religionist Southern slave holder, In the course of preaching to the slaves, he asked them a question, if they would want to be free. The slaves of course replied, "O, no massa." The response gave the Reverend gentleman the satisfaction he required for his propaganda in the North before the abolitionists, in favour of slaving in the South;

He comes home to publish" Southern side view on slavery" and to explain of the exaggerations of abolitionists. He assures people that he had been to the South, and seen slavery for himself; that it is a beautiful "patriarchal institution" that the slaves don't want their freedom; that they have hallelujah meetings and other religious privileges (115).

What else could have been the response of the slaves? If they had replied negatively they would face torture from their master instantly, and the burden of their slavery would even be made worse for them. They were in fact in a dilemma, and their response was only the safest one for them at least for that moment. But this in no way represented the true position of their wish.

There was also a report of a clear defense of the institution of slavery by a renowned senator, Brown of Mississippi who stood up in the congress of the United States and declared that, "Slavery was great moral, social and political blessings; a blessing to the master; and a blessing to the slave" (184).

Of course no slave ever accepted freely to remain in servitude, Even Solomon under the service of his kind master, Mr. William Ford still cherished his freedom more especially when he described his separation from his family by servitude. This explains why he says: "I think of him with affection, and had my family been with me, could have borne his gentle servitude, without murmuring, all my day... (74).

Not every slave had the opportunity to struggle or even long for freedom. The laws favoured the institution of slavery and spelt doom for any slave that attempted to escape. Movement of slaves was fully controlled to check the incident: of runaway slaves, the three narratives being considered, examine the importance of education in the emancipation of slaves.

The emancipation of Solomon Northup was a function of his education. He acquired education ever before his captivity; he was a free man who had rights to enjoy, but lost all of them to servitude. At the early part of his life as a slave, he asserted his right of freedom as a free citizen of New York. The futility of this open means made him to resort to a more creditable skill of education, letter writing, in securing his emancipation.

The first letter was channeled secretly through the sailor, John Manning. According to Solomon: I directed the letter to Henry B. Northup of Sandy Hill-stating that I had been kidnapped, I was then on board the Brig Orleans, bound for New-Orleans; that it was then impossible for me to conjecture my ultimate destination, and requesting he would take measures to rescue me. The letter was sealed and directed, and Manning having read it, promised to deposit it in the New-Orleans post office (47),

Another attempt by Solomon was to channel a letter through an overseer in the neighbouring plantation, $\mathrm{Mr}$. Armsby. Armsby or Mr. Epps leaked what was meant to be a top secret; Solomon would have gone in on two count charges his acquisition of education and his longing for freedom. Based merely on the report of Armsby, Mr Epps went and directed his question to Solomon saying: "Well boy"... I understand I've got a lamed nigger that writes letters and tries to get white fellows to mail'em. Wonder if you know who he is?..," (177)This bid having failed, Solomon made the final an successful attempt on letter writing, which this time was routed 
through one Mr. Bass, a white technician, opposed to the institution of slavery. This time around, Solomon directed the letter to his acquaintances in the North, Mr. Cephas ParKerand William Perry. It reads thus: Bayon Boenf, August 15,1852.

Mr. William or Mr. Cephas Parker.

Gentlemen it having been a long time since I have seen or heard from you. It is with uncertainty that I write to you, but the necessity of the case must be my excuse. Having been born free, just across the river from you, I am certain you must know me, and I am here now a slave. I wish you to obtain free papers for me, and forward them to me at Marksville, Louisiana, Parish of Avoyelles, and oblige. Yours, Solomon Northup (212).

It was this letter that, paved way for the emancipation of Solomon as he later confesses thus: I am indebted to Mr. Henry B. Northup and others, the letter, directed to Parker and Perry, and which was deposited in the post office in Marksville on the 5th day of August, 1852, arrived at Saratoga in the early part of September...Messrs Parker and Perry on receipt of the letter forwarded it immediately to Anne, on reading it, the children were all excited and without delay hastened to the neighbouring village of Sandy Hill, to consult Henry B. Northup and obtain his advice and assistance in the matter... (225-6).

The role of education in the emancipation of slaves, as already noted cannot be overemphasized. As a slave, one lost all his rights as a human being: but with education, one appreciated and asserted these rights, which could only be recovered through emancipation.

In consequence to the impact of education on slaves and even on man generally, slave holders were unsettled seeing them learning how to write or spell. In his narrative, Frederick Douglass reveals his experience under Mr. and Mrs. Auld in his bid to acquire education: . It was unlawful as well as unsafe to teach a slave to read. Mr. Auld said, "if you give a nigger an inch, he will take an ell. A nigger should know nothing but to obey his master to do, as he is to do, Learning would spoil the best nigger in the world.; if you teach that nigger how to read, there would be no keeping him,..(78).

But the negative attitude of Auld and wife to Douglass education rather posed a challenge to Douglass. He was bent, on acquiring the education despite the absence of a teacher to impart the knowledge to him. Thus, he says: Though conscious of the difficult of seaming without a teacher, I set out with hope, and a fixed purpose at whatever cost of trouble to learn how to read. The very decided manner with which he spoke and strove to impress his wife with the evil consequences of giving me instruction served to convince me that he was deeply sensible of the truths he was uttering. It gave me the best assurance that I might rely with the utmost confidence on the results, which he said, would follow from teaching me to read (79).

The fruit of this education is evident in his subsequent years. First, he organized Sabbath school for his fellow slaves at least to give them mental freedom, no slave holder would allow them to have. According to Douglass: I held my Sabbath school at the house of a free coloured man. The work of instructing my dear fellow slaves was the sweetest engagement with which I was ever blessed. We loved each other; to leave them at the close of the Sabbath was a severe cross indeed... and I have the happiness, that several of those who came to Sabbath school learned how to read; and that one at least is now free through my agency (120-121).

Incidentally it was with this crop of slaves whom he groomed in his Sabbath school, that he plotted the means of ensuring their emancipation:

At the close of the year, 1934, Mr. Free/and again hired me of my master, for the years, 1835 . But by this time I began to want to live upon Freeland as well as with Freeland and / was no longer content, therefore, to live with him or any other slave holder. I began with the commencement of the year to prepare myself for a final struggle, which should decide my fate one way, or the other., my fellow slaves were dear to me. I was anxious having them participate with me in this my life-giving determination. I bent myself to devising ways/means for our escape,../ went first to Henry, next to John, then to the others. I found in them all, warm? hearts and noble spirits (122).

Finally, it was his experience as an educated man that enabled him to play a leading role in this plot by faking up a pass for all of them involved in the deal, just about one week to the day of departure. The pass reads thus: ...This is to certify that I, the undersigned, have given the bearer, my servant, full liberty to go to Baltimore, and spend the Easter holidays, Written with mine own hand, \& C., 1835. WILLIAM HAMILTON New St. Michael in Telbot County, Mary land. (122),

Acquisition of educational skills also played a major role in the emancipation process of Linda Brent. Unlike many slaves, she received her elementary education from her mistress. "While I was with her, she taught me to read and spell; and for this privilege, which so rarely falls to the lot of a slave, I bless her memory ${ }^{11}(16)$. Slave holders general disapproval towards the education of their slaves still applied to Linda later in life. The first person that demonstrated this was Dr. Flint, under whom Linda served after the death of her mistress. According to Linda:

One day, he caught me teaching myself to write. He frowned, as if he was not well pleased; but I supposed he came to the conclusion 
that such an accomplishment might help to advance his favourite scheme ...(16).

Also, while Linda was in her grandmother's house, a company of white youths came to search the house. In the course of this exercise, a number of letters were discovered. The captain of the company inquired who wrote and Linda replied that it was one of her friends. But when later Linda was asked a question "Can you read?" and she affirmed, the captain did not hesitate to swear and then tore the paper into bits and shreds in total disapproval of Linda's acquisition of education.

Based on her education, Linda exploited the benefits of letter writing. Her first letter was cunningly directed to Dr, Flint to give him the impression that she succeeded in crossing to the North; while in actual fact she was in her dungeon underneath the grandmother's house, after her escape from Mr. Flint's plantation. Linda informs us:

Dr. Flint had not given me up...I wrote two letters, one to my grandmother, the other to Dr. Flint I reminded him how he, a gray-headed man, had treated a helpless child, who had been placed in his power, and what years of misery he had brought upon her. To my grandmother, I expressed a wish to have my children sent to me at the north, where I could teach them to respect themselves... I asked her to direct her answer to a certain street in Boston, as I did not live in New York, though I went there sometimes... it was necessary to tell my grandmother what I had done... and prepared to hear what Dr Flint might say about my being at the north (195-6).

When eventually Linda successfully crossed over to the North another letter was written to Dr, Flint at the instance of her grandmother. The objective of this letter was to request him to sell her

(Linda.) to her grandmother as a way of formally guaranteeing her ultimate andunmolested freedom. Apart: from Dr. Flint, she equally established content with her Southern friends through correspondence, all in the bid to achieve full freedom. Thus, Linda explains:

In order to protect my children, it was necessary that I should own myself. I called myself free and sometimes felt so, but I knew I was insecure; I sat down that night and wrote a civil letter to Dr. Flint, asking him to state the lowest terms on which he would sell me, and as I belonged by law to his daughter, I wrote to her also, asking a similar request (253).

It was through his correspondences with the South that she was able to monitor the intentions, plans and opinions of Dr. Flint about her. Her awareness of Dr, Flint's plans on the other hand, enabled her to tighten and consolidate her own security arrangement, until she eventually secured .full freedom. All these were fruits and functions of her education.

The basic hallmarks of an ideal slave narrative border on the narrator's experiences as a slave, his or her heroic journey from slavery to freedom and his subsequent dedication to abolitionist principles and goals, the three narratives display a plus in highlighting these important aspects In their narratives. Interestingly, all the three narratives assume almost a common pattern of structural representation, both in their tone of language and arrangement of facts, reflecting the beginning of the journey and its end, leading to freedom,

Two factors are identified as having played unique roles in the lives and freedom of the slaves. One is education and the other, their nativity or birth status. For instance, Solomon Northup became a slave at 32, after he had enjoyed the status of a free citizen of New York from birth, and received his normal education as a bonafide free coloured citizen of that city. Education just like others apart from influencing his competence and his public relations during his servitude under various masters, aids him in organizing secretly and in articulate manner, for his freedom through his correspondences with his relatives in the North. Besides, it equips him to have vivid recollections of the incidents in his slave life even after the servitude, a factor, which made possible the compilation of his volume, a masterpiece of a slave narrative, despite the fact that the period of servitude lasted up to twelve years.

Similarly, education is an indispensable factor in the life and emancipation of Linda and Frederick Douglass. However, their parental backgrounds as slaves automatically confer on them the status of slaves from birth. As slaves, they do not enjoy the opportunity of enquiring formal education, as did Solomon. But on their own, their little contact with education and the unwillingness of their respective masters to allow them freedom to acquire education, rather serve as a challenge to acquire same. They benefit immensely from the acquisition of this skill particularly during their plot for freedom.

However, unlike Solomon, the freedom of Linda and Douglass does toe legal process. Only the extra legal process adopted by them would have guaranteed their freedom as no Southern slave holder is prepared to be free of his slave even at old age. The case of Marthy, the grandmother of Brent Linda who at a very old age still has to be auctioned by Dr. Flint, the master, is pertinent.

Finally, it is common among the narrators to reveal the objective of their respective projects. They all point at common reason for the undertaking to explore the horrors of slavery in the South, thereby, debunking the false 
propaganda in the North by protagonists of the institutions who project it as a worthwhile venture that benefit both the master, and slaves alike. The narrators are unanimous too in whipping up sentiments of the general public towards the abolition of the nefarious activity. Some of the presentations would appear fictitious, but the persistent assurance of the narrator that the facts are real would makes virtually every reader of these narratives to score very highly the wonderful recollections of the narrators in compiling such articulate volumes despite the fact that they operate under traumatic conditions and have no documentations all through their period of servitude to rely on.

\section{WORKS CITED}

Bruner, Jerome. "The Autobiographical Process" in Robert Forikenflik (ed). The Culture of Autobiography: Construction of Self-Representation, California, Stanford UP, 1993.

Douglass, Frederick, Narrative of the Life of Frederick Douglass an American Slave, New York, Penguin 1983. Jacobs, Harriet, Incidents in the Life of a Slave Girl, New York, Oxford Up, 1988.

Northup, Solomon, Twelve Years a Slave, Baton Rouge: Louisiana State, 1968.

Ogude, J. E "Phillis Wheatley: Poems and Letters", Genius in Bondage: A Study of the Origins of African Literature. He Ife Uoflfe, 1983. 